\title{
Effects of topical application of essential oil from resin of almescar (Protium heptaphyllum (Aubl.) Marchand) in experimentally induced skin wounds in rats*
}

\author{
Avaliação da aplicação tópica do óleo de caule de alméscar \\ (Protium heptaphyllum (Aubl.) Marchand) em feridas cutâneas \\ experimentalmente induzidas em ratos
}

\author{
Wherick A. Bernadi, ${ }^{* *}$ Jéssica de C. Zanotelli, ${ }^{* * *}$ Ewelyne Miranda de Lima, ${ }^{* * *}$ Tayse Domingues de Souza, ${ }^{* * *}$ \\ Denise Coutinho Edringer, ${ }^{* * \star * *}$ Vinicius Ricardo Cuña de Souza******
}

\begin{abstract}
The aim of this study was to evaluate clinical and histopathological aspects of topical application of almescar (Protium heptaphyllum (Aubl.) Marchand) oil resin on the healing processes of experimentally induced wounds in rats (Rattus norvegicus). Male rats ( $\mathrm{n}=16$ ) were randomly distributed into two experimental groups: group treated with almescar oil resin at $0.5 \%$ in isotonic solution (GO, $\mathrm{n}=8$ ) and control group ( $C G, n=8)$. The experimental lesions were treated daily for 30 days. Macroscopic and histopathological analyses were performed on days 3, 7, 14 and 21 , respectively. A wound contraction of $94.77 \%$ was recorded for GO and $93.91 \%$ 21 days after the lesion. The chemical constituents identified in the essential oil were predominantly monoterpenes, $\alpha$-terpinolene $(32.7 \%)$, limonene $(22.0 \%)$ and 3-carene (15.0\%) were identified as major components. Wounds in both groups had a significant reduction in the wound area during the trial period $(p<.0001)$. Comparing the groups in different stages of evaluation, there were significant differences on day $3(p=0.0268)$, day $7(p=0.0031)$ and day $14(p=.0190)$. In conclusion, the topical application of almescar resin oil was beneficial in the healing process of experimentally induced skin wounds in rats, making it a therapeutic option in veterinary medicine.
\end{abstract}

Keywords: Almescar, Healing, Phytotherapy, Rats, Wounds.

\section{Resumo}

O objetivo deste estudo foi avaliar os aspectos clínicos e histopatológicos da aplicação tópica do óleo da resina do alméscar (Protium heptaphyllum (Aubl.) Marchand) no processo de cicatrização de feridas cutâneas induzidas experimentalmente em ratos (Rattus norvegicus). Ratos machos $(n=16)$ foram distribuídos aleatoriamente em dois grupos experimentais: grupo tratado com resina de óleo alméscar em $0,5 \%$ em solução isotônica $(\mathrm{GO}, \mathrm{n}=8)$ e grupo controle $(\mathrm{GC}, \mathrm{n}=8)$. As lesões experimentais foram tratadas diariamente durante 30 dias. Análises macroscópicas e histopatológicas foram realizadas nos dias $3,7,14$ e 21 . Grau de contração de $94,77 \%$ foi registrada no grupo tratado com o óleo de resina e de 93,91\% para as feridas controle após 21 dias de tratamento. Os constituintes químicos identificados no óleo essencial foram predominantemente monoterpenos, entre estes, $\alpha$ - terpinoleno $(32,7 \%)$, limoneno $(22 \%)$ e 3-careno (15\%) em sua maioria. As feridas de ambos os grupos tiveram uma redução significativa na área durante o período experimental $(p<0,0001)$. Comparando-se os grupos em diferentes etapas de avaliação, houve diferença significativa no dia $3(p=0,0268)$, dia $7(p=0,0031)$ e dia $14(p=0,0190)$. Em conclusão, a aplicação tópica de óleo de resina alméscar foi benéfica no processo de cicatrização de feridas cutâneas induzidas experimentalmente em ratos, tornandose uma opção terapêutica em medicina veterinária.

Palavras-chave: alméscar, cicatrização, fitoterapia, ratos, feridas.

\section{Introduction}

A wound is the result of an injury (accidental type) or a surgical procedure (intentional trauma) (Garros et al., 2006). Healing is the dynamic process that reestablishes the integrity of the skin. The healing process can occur by primary intention, when the wound can be sutured, or by secondary intention (or spontaneous healing), when the wound is left open to heal without surgical procedure by epithelization and contraction. Also there is the delayed primary closure where the surgical procedure is done after the reduction of the wound contamination (Magalhães et al., 2008).

\footnotetext{
${ }^{*}$ Recebido em 21 de abril de 2014 e aceito em 23 de março de 2015.

${ }^{* *}$ Programa de Mestrado em Ciência Animal (UVV-ES).

***Curso de Graduação em Medicina Veterinária (UVV-ES).

****Curso de Graduação em Farmácia (UVV-ES).

*****Programa de Pós-Graduação em Ciências Farmacêuticas (UVV-ES).

******Quality Clínica de Especialidades Veterinárias, Rua José Guilherme Neffa 140, CEP: 29092-070, Vitória-ES, Brasil.

Author for correspondence: viniciuscuna@yahoo.com
} 
The healing process comprises mainly three phases: inflammatory, proliferative and maturation. According to Mori et al. (2004) and Magalhães et al. (2008), soon after the injury, there is the extravasation of blood and clot formation, followed by accumulation of inflammatory debris and contamination. On the inflammatory phase there is the recruitment of leukocytes to the lesion site. In the proliferative phase, re-epithelization and formation of granulation tissue occurs with the migration and proliferation of keratinocytes, fibroblasts and endothelial cells. Finally, during the maturation phase, the degradation of collagen by various proteolytic enzymes promotes the reparation of the damaged tissue.

Skin wounds are very common in many species and the researches are made in rats in order to facilitate the experiments (Garros et al., 2006, Magalhães et al., 2008, Santos et al., 2009). The conventional therapies include allopathy, but sometimes the costs are extremely high. Because of this fact and the easy access to herbal medicines, many studies have been developed to prove the effectiveness. Examples include Eurides et al. (1996) using copaiba oil (Copaifera langsdorffii), Coelho et al. (2010) using the extract of ipê-roxo (Tabeluia avellanedae) and barbatimão (Stryphnodendron adstringens), Faleiro et al. (2009) using aloe vera leaves (Aloe barbadensis), Nitz et al. (2006) using daisy (Bellis perennis) and Garros et al. (2006) using passion fruit (Passiflora edulis) and Coelho et al. (2012) using sunflower-seed oil (Helianthus annus L.) for the treatment of cutaneous injuries in equine metatarsus.

Popularly known as almécega, alméscar, almíscar, breu-branco, the Protium heptaphyllum has a thick trunk about 10 meters high (50-60 cm in diameter at the base), dark red bark and its leaves are opposite, flowers are small, fruits are reddish and contain four seeds (Oliveira et al., 2004). It is a medicinal plant mainly found in the North and Northeast of Brazil. Popularly, several pharmacological activities were attributed to the resin, such as tonic, stimulant, anti-ulcer, anti-inflammatory, healing, analgesic and expectorant (Aragão et al., 2006). Oliveira et al. (2004) and Araujo et al. (2011) described its gastroprotective activity, possibly, by increasing COX-2 and EGF expression and due to its possible antioxidant property.

Despite its widespread use in popular medicine against various diseases, the use of crude resin as an anti-inflammatory agent has not yet been established in the literature. The present study aimed to demonstrate the effects of topical application of alméscar ( $P$. heptaphyllum) oil resin on the healing process of induced experimentally wounds skin in rats.

\section{Material and methods}

The study was reviewed and approved by the Committee of Ethics, Animal Welfare and Bioethics (CEUA - UVV - ES) of the Universidade Vila Velha (UVV - ES), Espírito Santo, Brazil (protocol number 71/2009).

\section{Animals}

The research included 16 male Wistar rats (Rattus norvegicus), mean age of 8 months and mean weight of $341 \pm 19 \mathrm{~g}$, kept at Laboratório de Acompanhamento Experimental (LAE - UVV ES), Vila Velha - ES, Brazil. All animals were kept in individual autoclaved plastic cages, lined with wood shavings receiving food and water ad libitum, and artificial lighting with a circadian cycle of 12 hours at a room temperature between $20-25^{\circ} \mathrm{C}$ during the experimental period. Animals $(n=16)$ were divided into two groups, treatment group (treated with essential oil from almescar resin in a spray form with at a concentration of $0.5 \%$ in $\mathrm{NaCl}$ $0.9 \%-\mathrm{GO}, \mathrm{n}=8$ ) and control group (treated only with isotonic solution of $\mathrm{NaCl} 0.9 \%-\mathrm{GC}, \mathrm{n}=8$ ).

\section{Materials}

The stem resin of alméscar, Protium heptaphyllum (Aubl.) March, was collected in May 2010 on the island of Guriri, Espírito Santo $\left(18^{\circ} 44^{\prime} 21^{\prime \prime S} 39^{\circ} 44^{\prime} 50^{\prime \prime} \mathrm{W}\right)$. The essential oil extraction was obtained as described by Skrubis (1982) and Ming et al. (1996), with slight modifications. Briefly, $1.5 \mathrm{~L}$ of deionized water and $250 \mathrm{~g}$ of the resin were added and the extraction lasted two hours. The hydrolate obtained was kept at $4^{\circ} \mathrm{C}$ in a dark environment. The oil was separated by cryo-separation. The oily fraction was filtered with anhydrous magnesium sulfate and then stored in amber bottle at $4^{\circ} \mathrm{C}$. The extraction yield was determined by the proportional relationship between the resin weight and the weight of the oil obtained. The oil was placed in an amber glass bottle and stored at $4^{\circ} \mathrm{C}$.

The analysis of the chemical constituents of the oil and was performed using gas chromatography (Trace Ultra, ThermoScientific $^{\circledR}$ ) coupled to a mass spectrometer (DSQII, ThermoScientific $\left.{ }^{\circledR}\right)$. The volatile substances were separated on a capillary column DB-5 (30 m x 0,25 mm d.i. $\times 0,25 \mu \mathrm{m}$, J\&W Scientific $\AA$, Folson California, USA). The samples were injected into the GC / MS in duplicate diluted with hexane (1 mg $/ \mathrm{mL}$ ), and the volume of $1.0 \mu \mathrm{L}$ was injected with the injector in splitless mode.

The identification of the substances contained in the oil was conducted by comparing the mass spectrometry data of the present study with those published by Adams (2007). The relative percentages of these compounds were calculated from the mean areas of the chromatograms obtained.

\section{Treatments}

To induce the wounds, animals were sedated with xylazine (1.0 $\mathrm{mg} / \mathrm{kg}$ ) and anesthetic protocol included ketamine $(30.0 \mathrm{mg} / \mathrm{kg})$, intraperitonally. After anesthesia, the dorsal area of each animal was clipped and aseptically prepared using povidone-iodine $5 \%$ solution and $70 \%$ alcohol.

A $1.5 \times 1.5 \mathrm{~cm}\left(2.25 \mathrm{~cm}^{2}\right)$ wound was surgically produced in the dorsal region of each animal with the aid of a scalpel handle 3 , blade 10 and shear-thin edge, using a plastic quadrangular mold. Excision depth included skin and subcutaneous tissue. All wounds were cleaned with sterile gauze containing saline solution $(\mathrm{NaCl} 0.9 \%)$ and dried with another clean gauze both sterile.

Treatment began 24 hours after surgery and then rats were weighed and randomly selected for each group. For both groups, wounds were cleaned with gauze formerly embedded in saline solution. After this, an amount of $300 \mu \mathrm{L}$ of $\mathrm{NaCl} 0.9 \%$ was applied on the GC wounds and an amount of $300 \mu \mathrm{L}$ of almescar solution (spray) was applied to wounds of the GO animals. After spraying the product, wounds were dried for 5 minutes before returning them to the cage containing wood shavings. 


\section{Macroscopical evaluation}

Daily, animals were weighed and the wounds of the dorsal region were used for macroscopical and histological evaluations. Subjective macroscopic evaluation (edema, hyperemia, exudate, granulation tissue and crusts) and objective area measurement (Vernier Calipers $150 \times 0.02$ mm [6"x 1/1000 IN] CLA 006 caliper rule) were performed on days $3,7,14$ and 21 postoperatively. The wound area was estimated by the equation $A=\pi \times R \times r$ ( $A$ is the area, $R$ is the larger measurement and $r$, the smaller measurement) (Prata et al., 1988). The image data were obtained soon after surgery on day 0 (zero), 3, 7, 14 and 21 using a Sony digital camera $\mathrm{H} 9$ CyberShot with a distance of $30 \mathrm{~cm}$. The degree of wound contraction was calculated using mathematical equation proposed by Ramsey et al. (1995): contraction (\%) = $100 \times($ Wo $-\mathrm{Wi}) /$ Wo, where Wo represents the original area of the wound; Wi represents the area of the wound at the time of evaluation $(3,7,14$ or 21 days).

\section{Histology}

For the histopathological evaluation, biopsy samples were obtained using a sterile metallic $6 \mathrm{~mm}$-punch on days $3,7,14$ and 21 after surgery. Anesthetic protocols were the same of the day for inducing the wounds and biopsies were performed in a clockwise direction. Skin segments included the wound and adjacent healthy area. Biopsied tissues were stored in $10 \%$ buffered formalin and sent to the Laboratório de Patologia Veterinária (UVV-ES). The material was processed and embedded in paraffin, sectioned at $5 \mu \mathrm{m}$ with a rotary microtome (Leica ${ }^{\circledR}$ RM 2125RT; Nussloch, Germany). Samples were stained with hematoxylin-eosin (H\&E).

Microscopic evaluation was conducted by a pathologist, without prior knowledge of the treatment, using magnification of $100 \mathrm{x}$ and 400x (Nikon Eclipse E200), looking for characteristics related to skin structures like the presence of inflammatory cells, crust, angiogenesis, fibroplasia, epithelialization and collagen tissue. The following classification was used: focal, multifocal, extensive and diffuse; and intensity, mild, moderate and severe for standardization and subsequent analysis of the data egalitarian.

On the thirtieth day, the animals were euthanized with a lethal dose of Thiopental Sodium $1 \mathrm{~g}(150 \mathrm{mg} / \mathrm{kg}$ body weight), intraperitoneally. After the procedure, organs fragment (lung, liver and spleen) were obtained for microscopic analysis to evaluate possible toxic effects.

\section{Statistical analysis}

Wound area data were analyzed using analysis of variance followed by Tukey test. Comparisons between the treatments for the different periods were made using Student $t$ test. A value of $p<.05$ was considered significant for all comparisons. All statistical analysis was performed using GRAPHPAD INSTAT 3.00 (GraphPad Software, CA, USA).

\section{Results and discussion}

In 2002, the World Health Organization (WHO) acknowledged the popular use of almescar ( $P$. heptaphyllum) by natives and researches on the subject are necessary to prove its efficacy on animals and humans for further recommendation for the treatment of wounds.
The yield of essential oil extraction from the resin of $P$. heptaphyllum was $14.4 \%(\mathrm{~g} / \mathrm{g})$ and the chemical constituents identified in the essential oil were predominantly monoterpenes, among these, a-terpinolene (32.7\%), limonene $(22.0 \%)$ and 3-carene (15.0\%) as major components. Bandeira et al. (2002) and Rao et al. (2007) verified the presence of monoterpenes on the oil as well as our study. Apart of the antinociceptive and anti-tumoral activities, these substances may be involved in the healing process.

No clinical abnormalities associated with the surgically induced wounds were observed during the experiments. Also no deaths occurred during the experiment. All rats had a good recovery from anesthesia and daily evaluations demonstrated good health and presence of regular physical activity.

The experimental model chosen was Wistar because of their small size, easy handling and acquisition, as well as the easy standardization of accommodation and food (Garros et al., 2006, Magalhães et al., 2008, Santos et al., 2009). Male rats are better for experiments because they do not undergo cyclic changes in hormone concentrations as females, a fact that could alter the healing process (Teves et al., 1986).

Evaluations of the present research were done on days 3, 7, 14 and 21 because these days are the most significant days on the healing process in rats according to Simões et al. (1986). Marques et al. (2004) and Garros et al. (2006) described the same protocol in their experiments to record the different phases of inflammatory process.

The dorsal region was chosen to avoid licking by the animals during the experimental period that could alter the evaluations or even the healing process, also because this location is the most used protocol of open wound study (Alvares et al., 1972). The square shaped wound on each animal was performed according to the experimental model used by Brito et al. (2001) and Sant'Ana (2012).

The mean values and standard deviations of the dorsal wound area for almescar resin oil group (GO) and control group (GC) are listed on Table 1. Significant reduction of the wound area was observed for both groups $(p<0.0001)$ during the experimental period. On the comparing of the groups on the different evaluating moments, there was a significant difference on day $3(p=$ $.0268)$, day $7(p=.0031)$ and day $14(p=.0190)$. On day 21 , there was no significant difference between groups $(p=.5686)$. The contraction of healing wounds recorded in the GC and GO were, respectively, $93.91 \%$ and $94.77 \%$ at the end of the experimental period. Magalhães et al. (2008) found $77.95 \%$ and $83.49 \%$, respectively, for control group and group treated with test formulation (containing medium chain triglycerides, linoleic acid, vitamins $A$ and $E$ and soy lecithin).

On the 3rd day of treatment, there was an increase on lesion size on both groups. The infiltration of polymorphonuclear cells on the first three days corresponds to the inflammation phase, which is crucial for the healing process. At this period, analyses revealed a moderate multifocal inflammation and the presence of crust with infiltration of polymorphonuclear cells on GC. Discretely to mild inflammation and the presence of crust and inflammatory exudate and mild fibroblast proliferation were observed for GO, suggesting a less intense inflammatory response which is beneficial for the healing process (Rahal et al., 2003). This 
Table 1: Mean values and standard deviations of the areas of wound healing between the control group (CG) and essential oil of almescar resin group (GO), both experimentally induced in rats

\begin{tabular}{cccccc}
\hline & Day 0 & Day 3 & Day 7 & Day 14 & Day 21 \\
\hline GO & $7.07 \pm 0.00^{\mathrm{aA}}$ & $7.18 \pm 1.45^{\mathrm{aA}}$ & $2.41 \pm 0.46^{\mathrm{bA}}$ & $0.51 \pm 0.29^{\mathrm{bcA}}$ & $0.37 \pm 0.22^{\mathrm{dA}}$ \\
CG & $7.07 \pm 0.00^{\mathrm{aA}}$ & $9.86 \pm 2.70^{\mathrm{bB}}$ & $4.23 \pm 1.37^{\mathrm{cB}}$ & $0.84 \pm 0.20^{\mathrm{cdB}}$ & $0.43 \pm 0.19^{\mathrm{dA}}$
\end{tabular}

*Different lowercase letters on the same line denote significant differences $(p<.05)$ on Tukey test. Different uppercase letters in the same column denote significant difference $(p<.05)$ on t-test.

reduced inflammation was confirmed by Siani et al. (1999) that studied in vivo effect of Protium spp. resin and leaves in rats and concluded that the oil inhibited the extravasation of protein. Oliveira (2005) also described the anti-inflammatory effects of $P$. heptaphyllum. According to Oliveira et al. (2004), possibly the resin inhibits more potently the mast cell mediators and affects the vascular permeability increase.

After this, the contraction of the lesions began in both groups, representing an important process for closure of the lesions (Ferreira et al., 2008).

Although the wound area was reduced gradually in both groups tested, as shown on Table 1 , the reduction was faster on GO during the first two weeks of evaluation. Similar results were observed by Garros et al. (2006) but on their research with Passiflora there were no differences between control and treatment groups. Apart of the anti-inflammatory effects, Araujo et al. (2011) demonstrated the antioxidant effects of Protium due the action of monoterpenes. According to the authors, Protium reduces malondialdehyde (MDA) production, a final product of lipidic peroxidation. Similar antioxidant effects was described by Magalhães et al. (2008) for E vitamin, which leads to a better healing process because it minimizes the effects of free radicals.

The collagen fibers appear arranged in parallel around the 14th day after injury, event that coincides with proliferative phase (Alvares 1972).

On the present research, different from Alvares (1972) and similar to Santos et al. (2006), it was observed a new epithelization beginning on the edges of the lesion and a parallel arrangement of collagen fibers on the GO on day 7 of treatment, while on the GC the only change between the day 3 and day 7 consisted of a fibroblast proliferation.

On the 14th day of evaluation, there was mild focal inflammation in GC while on the GO a new epithelization was already present from the edges of the lesion. The intense epithelization process on the GO was also characterized by a mild inflammatory reaction and the presence of new blood vessels and fibroblasts in directions perpendicular to each other. According Modolin and Belivacqua (1985), regression endothelial begins with the formation of focal hyperplasia at the margins of the lesion and its continuity to complete the new epithelization of the surface (Figure 1).

On day 21, the macroscopical signs confirmed an advance on the healing process of the GO wounds (Figure 2). Histopathological analysis showed contraction of collagen fibers and presence of myofibroblasts. The GC revealed the presence of collagen matrix deposition and scar structural arrangement well evidenced.

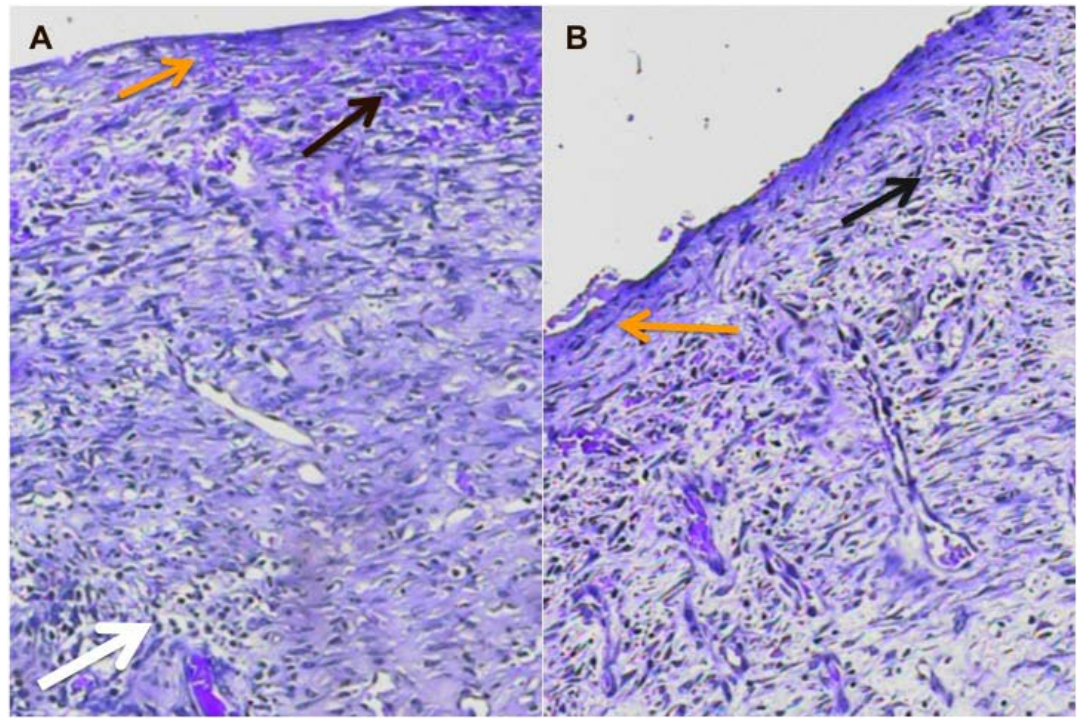

Figure 1: Digital image depicting the histological aspect of the skin wounds on the dorsal region of rats $(40 x)(H \& E)$. (A) Histological section of the skin of the animal in the control group in the 14th day of the experiment demonstrating the presence of inflammation (white arrow) and mild hemorrhage (black arrow), remodeling of blood vessels and scar tissue organization (orange arrow). (B) Histological section of the skin of the almescar resin oil group in the 21st day of the experiment demonstrating the incomplete epithelization (orange arrow), moderate degree of inflammation and hemorrhage (black arrow) and disorganized scar tissue (white arrow).

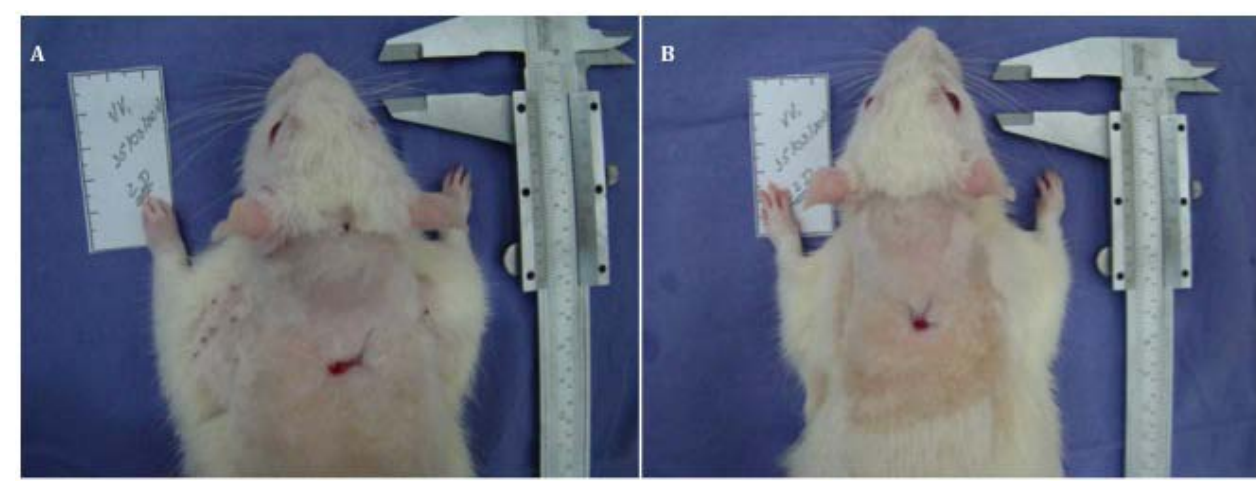

Figure 2: (A) Skin wounds on the dorsal region of animal of control group on day 21 of treatment. (B) Skin wounds on the dorsal region of animal of almescar resin oil group on day 21 of treatment. 
The daily evaluations of the size of the wounds are consistent with Sant'Ana's research (2012) using the same methodology to evaluate the influence of andiroba oil on the healing process of skin wounds of rats. Results of the present research showed a better wound contraction probably due antioxidant effects as discussed above.

Necropsy did not show changes on examined organs that could be related to the use of the resin oil demonstrating that its absorption through the skin does not lead to toxic effects. This observation was also described by Araujo et al. (2011). In addition, animals had a body weight gain of $10 \%$ during the experimental period (mean body weight of $329.67 \mathrm{~g}$ two weeks before the beginning and $362.57 \mathrm{~g}$ on the last day).

\section{Conclusion}

Because of the lower intensity of the inflammatory process and the observation of focal hyperplasia of the margins of the lesion noted early in the GO, it can be stated that the topical application of essential oil from almescar resin ( $P$. heptaphyllum), at a concentration of $0.5 \%$ helped the healing process, thus justifying its use in veterinary medicine.

\section{Acknowledgment}

The work was supported with funds from FUNADESP, FAPES and UVV. Tommasi Analítica is acknowledged for the help in the chromatographic analyses.

\section{References}

ADAMS, R.P. Identification of essential oil components by gas cromatography/mass spectroscopy. 4. ed. Carol Stream (USA): Allured Publishing Corporation, 2007, 804 p.

ALVARES, S. Contribuição para o estudo histométrico e histoquímico do processo de reparação de lesões obtidas experimentalmente na pele de ratos albinos. 1972. $117 \mathrm{f}$. Tese (Doutorado) - Faculdade de Odontologia - Universidade de São Paulo, SP, 1972.

ARAGÃO, G.F.; CARNEIRO, L.M.V.; JUNIOR, A.P.F.; VIEIRA, L.C.; BANDEIRA, P.N.; LEMOS, T.L.; VIANA, G.S. A possible mechanism for anxiolytic and antidepressant effects of alphaand beta-amyrin from Protium heptaphyllum (Aubl.) March. Pharmacololy, Biochemistry and Behavior, v. 85, n. 4, p. 827-834, 2006.

ARAUJO, D.A.O.; TAKAYAMA, C.; DE FARIA, F.M.; SOCCA, E.A.R.; DUNDER, R.J.; MANZO, L.P.; LUIZ-FERREIRA, A.; SOUZA-BRITO, A.R.M. gastroprotective effects of essential oil from Protium heptaphyllum on experimental gastric ulcer models in rats. Revista Brasileira de Farmacognosia, v. 21, n. 4, p. 721729, 2011.

BANDEIRA, P.N.; PESSOA, O.D.L; TREVISAN, M.T.S.; LEMOS, T.L.G. Metabólitos secundários de Protium heptaphyllum March. Quimica Nova, v. 25, n. 6B, p. 1078-1080, 2002.

BRITO, N.M.B.; SILVA, P.R.F.; SILVA, G.C.F.; CASELLA, S.F.M.; SAMPAIO, A.R.S. Avaliação macroscópica de feridas cutâneas abertas, em ratos, tratadas com óleo de andiroba. Revista Paraense de Medicina, v. 15, n. 2, p.17-22, 2001.

COELHO, J.M.; ANTONIOLLI, A.B.; SILVA D.N.; CARVALHO, T.M.M.B.; PONTES, E.R.J.C.; ODASHIRO, A.N. O efeito da sulfadiazina de prata, extrato de ipê-roxo e extrato de barbatimão na cicatrização de feridas cutâneas em ratos. Revista do Colégio Brasileiro de Cirurgia, v. 37, n.1, p. 45-51, 2010.

COELHO, C.S.; GAMA, J.A.N.; OLIVEIRA JÚNIOR, L.A.T.; SILVA B.S.F.; SOUZA, V.R.C.; ENDRINGER D.C., LENZ, D. Use of extracts of sunflower-seed oil (Helianthus annus L.) for the treatment of cutaneous injuries in equine metatarsus: a case report. Revista Brasileira de Plantas Medicinais, v. 14, n. 1, p. 125-129, 2012.
EURIDES, D.; MAZZANTI, A.; BELLETI, M.E.; SILVA, L.A.F.; FIORAVANTE, M.C.S.; NETO, S.T.; CAMPOS, V.A.; LEMOS, R.C.; JUNIOR, P.L.S. Morfologia e morfometria da reparação tecidual de feridas cutâneas de camundongos tratadas com solução aquosa de barbatimão (Stryphynodendron barbatiman Martius). Revista da FZVA, v. 2/3, n.1, p. 30-40. 1995/1996.

FALEIRO, C.C.; ELIAS, S.T.H.; CAVALCANTI, L.C.; CAVALCANTI, A.S. O Extrato as Folhas de Babosa, Aloe Vera na Cicatrização de Feridas Experimentais em Peles de Ratos, num Ensaio por Placebo. Natureza On line, v. 7, n. 2, p. 56-60, 2009.

FERREIRA, A.S.; BARBIERI, C.H.; MAZZER, N.; CAMPO, A.D.; MENDONÇA, A.C. Mensuração de área de cicatrização por planemetria após aplicação do ultrassom de baixa intensidade em pele de rato. Revista Brasileira de Fisioterapia, v. 12, n. 5, p. 351-358, 2008.

GARROS, I.C.; CAMPOS, A.C.L.; TÂMBARA, E.M.; TENÓRIO, S.B.; TORRES O.J.M.; AGULHAM, M.A.; ARAÚJO, A.C.F.; SANTIS-ISOLAN, P.M.B.; OLIVEIRA, R.M.; ARRUDA, E.C.M. Extrato de Passiflora edulis na cicatrização de feridas cutâneas abertas em ratos: estudo morfológico e histológico. Acta. Cirurgica Brasileira, v. 21, suplemento 3, p.55-65, 2006.

MAGALHÃES, M.S.; FECHINE, F.V.; MACEDO, R.N.; MONTEIRO, D.L.; OLIVEIRA, C.C.; BRITO, G.A.; MORAES, M.E.; MORAES, M.O. Effect of a combina- tion of medium chain triglycerides, linoleic acid, soy lecithin and vitamins $A$ and $E$ on wound healing in rats. Acta Cirurgica Brasileira, v. 23, n. 3, p. 262269, 2008

MING, L.C.; FIGUEIREDO, R.O.; MACHADO, S.R.; ANDRADE, R.M.C. Yield of essential oil of and citral content in different parts of lemongrass leaves (Cymbopogon citratus (D.C.) Stapf.) Poaceae. Acta Horticulturae, v. 426, p. 555-559, 1996.

MODOLIN, M.; BELIVACQUA, R.G. Cicatrização das feridas. Síntese das aquisições recentes. Revista Brasileira de Clínica Terapêutica, v.14, n. 6, p. 208-213, 1985.

MORI, R.; KONDO, T.; NISHIE, T.; OHSHIMA, T.; ASANO, M. Impairment of skin wound healing in b-1,4-galactosyltransferasedeficient mice with reduced leukocyte recruitment. American Journal of Pathology, v.164, n. 4, p. 1303-1314, 2004. 
NITZ, A.C.; ELY, J.B.; ACAMPORA, A.J.; TAMES, D.R.; CORREAA, B.P. Estudo Morfométrico no Proccesso de Cicatrização de Feridas Cutâneas em Ratos, usando: Coronopu didymus e Calendula offcinal. Arquivos Catarinenses de Medicina, v. 35, n. 4, p. 74-79, 2006.

OLIVEIRA, F.A. Estudo das propriedades farmacológicas da resina de Protium heptaphyllum (Albl.) March. e seus principais constituintes, mistura de $\alpha$ - e $\beta$-amirina. 2005. 279 f. Dissertação (Mestrado) - Faculdade de Medicina - Universidade Federal do Ceará, Fortaleza, 2005.

OLIVEIRA, F.A.; VIEIRA-JÚNIOR, G.M.; CHAVES, M.H.; ALMEIDA, F.R.C.; FLORÊNCIO, M.G.; LIMA, R.C.P.; SILVA, R.M.; SANTOS, F.A.; RAO, V.S.N. Gastroprotective and antiinflammatory effects of resin from Protium heptaphyllum in mice and rats. Pharmacological Research, v. 49, n. 2, p.105-111, 2004.

PRATA, M.; HADDAD, C.; GOLDENBERG, S. Uso tópico do açúcar em ferida cutânea: estudo experimental em ratos. Acta Cirurgica Brasileira, v. 3, n. 2, p. 43-48, 1988.

RAHAL, S.C.; BRACARENSE, A.P.F.R.L.; TANAKA, C.Y.; GRILLO, T.P.; LEITE, C.A.L. Utilização de própolis ou mel no tratamento de feridas limpas induzidas em ratos. Archives of Veterinary Science, v. 8, n.1, p. 61-67, 2003.

RAMSEY, D.T.; POPE, E.R.; WAGNER, M.A.N.N.C.; BERG, J.N.; SWAIN, S.F. Effects of three occlusive dressing materials on healing of full thickness skin wounds in dogs. American Journal of Veterinary Research, v. 56, n. 7, p. 941-949, 1995.

RAO, V.S.; MAIA, J.L.; OLIVEIRA, F.A.; LEMOS, T.L.G.; CHAVES M.H.; SANTOS, F.A. Composition and Antinociceptive Activity of the Essential Oil from Protium heptaphyllum Resin Nat. Prod. Commun. v. 2, n.12, p. 1199-1202, 2007.
SANT' ANA, G.C.S.F. Efeito terapêutico do óleo de andiroba ozonizado no processo de cicatrização de feridas cutâneas em ratos da linhagem Wistar. 2012. 89 f. Dissertação (Mestrado) Programa de Mestrado em Ciência Animal - Universidade Vila Velha, Vila Velha, 2012.

SANTOS, M.F.S.; CZECZKO, N.G.; NASSIF, P.A.N.; RIBASFILHO, J.M.; ALENCAR, B.L.F.; MALAFAIA, O.; RIBAS, C.A.P.M.; TRAUTWEIN, V.M.; HENRIQUES, G.S.; MAIA, J.M.A.; BITTENCOURT, R.C.A. Avaliação do uso do extrato bruto de Jatropha gossypiifolia L. na cicatrização de feridas cutâneas em ratos. Acta Cirurgica Brasileira, v.21, suppl. 3, p. 2-7, 2006.

SANTOS, J.S.; VIEIRA, A.B.D.; KAMADA, I. A Rosa Mosqueta no tratamento de feridas abertas: uma revisão. Revista Brasileira de Enfermagem, v. 62, n. 3, p. 457-462, 2009.

SIANI, A.C.; RAMOS, M.F.S.; DE LIMA, M.O.; SANTOS, R.; FERREIRA, F.E.; SOARES, E.C. Evaluation of anti-inflammatoryrelated activity of essential oils from the leaves and resin of species of Protium. Journal of Ethnopharmacology, v. 66, n. 1, p. 57-69, 1999.

SIMÕES, M.J.; CABRAL, A.C.V.; BOYACIYAN, K.; KULAY JR., L.; SASSO, W.S. Aspectos ultra-estruturais dos fibroblastos e dos macrófagos durante o processo de reparaçäo da pele de ratos. Revista Paulista de Medicina, v.104, n. 3, p.132-135, 1986.

SKRUBIS, B.G. The drying of laurel leaves. Perfumer \& Flavorist, V. 7, n. 5 , p. $37-40,1982$.

TEVES D.C.; CABRAL A.C.V.; SIMÕES M.J.; KULAY J.R.L. Biologia das reparações teciduais. Jornal Brasileiro de Medicina, v. 50 , n. 5 , p. 39-44, 1986. 